ISSN-L 1561-0837; eISSN: 1727-9933

Universidad Nacional Mayor de San Marcos

\title{
Two new species of Kalcerrytus Galiano, 2000 (Araneae: Salticidae) from Tambopata River, Madre de Dios, Peru
}

\author{
Dos especies nuevas de Kalcerrytus Galiano, 2000 (Araneae: Salticidae) del Río Tambopata, \\ Madre de Dios, Perú
}

\section{Bryan Portuguez*}

https://orcid.org/0000-0002-6218-1658

bjportuguez2@gmail.com

\section{*Corresponding author}

Departamento de Entomología, Museo de Historia Natural, Universidad Nacional Mayor de San Marcos, Apartado 14-0434, Lima14, Perú.

\section{Citación}

Portuguez B. 2021. Two new species of Kalcerrytus Galiano, 2000 (Araneae: Salticidae) from Tambopata River, Madre de Dios, Peru. Revista peruana de biología 28(3): e21109 (Agosto 2021). doi: http://dx.doi. org/10.15381/rpb.v28i3.21109

$\begin{array}{ll}\text { Presentado: } & 05 / 03 / 2021 \\ \text { Aceptado: } & 21 / 06 / 2021 \\ \text { Publicado online: } & 30 / 08 / 2021\end{array}$

Editor:

Diana Silva

\section{Abstract}

Jumping spiders of the genus Kalcerrytus inhabit the moist tropical forests of the Neotropical region. This genus includes 18 species, only both sexes are known for half of these and of $K$. leucodon only the female is known; the vast majority of species are registered for Brazil and there are records from Bolivia, Ecuador and French Guiana. Males are characterized by having a robust palp and more sclerotized than in other genera of the Freyina subtribe; females are distinguished by their broad epigynum with large funnel-shaped copulation openings and oblique edges. Two new species are herein described, and they represent the first record of the genus in Peru. Kalcerrytus mapinguari sp. nov. and Kalcerrytus yacuruna sp. nov. were collected in the Tambopata River region, which is characterized by its highly biodiverse tropical lowland evergreen forests. Illustrations of both male and female genitalia are provided as well as maps recording their distribution.

\section{Resumen}

Las arañas saltarinas del género Kalcerrytus habitan en los bosques tropicales húmedos de la región neotropical. Este género incluye 18 especies, solo se conocen ambos sexos para la mitad de estas y de $K$. leucodon solo se conoce la hembra; la gran mayoría de las especies están registradas para Brasil y existen registros de Bolivia, Ecuador y Guyana Francesa. Los machos se caracterizan por tener un palpo robusto y más esclerotizado que en otros géneros de la subtribu Freyina; las hembras se distinguen por su ancho epigino con grandes aberturas de copulación en forma de embudo y bordes oblicuos. Aquí se describen dos nuevas especies que representan el primer registro del género en Perú. Especímenes pertenecientes a Kalcerrytus mapinguari sp. nov. y Kalcerrytus yacuruna sp. nov. fueron recolectados en la región del río Tambopata, que se caracteriza por la alta biodiversidad que exhiben sus bosques amazónicos bajos. Aquí se proporcionan ilustraciones de la genitalia del macho y de la hembra, así como mapas que registran su distribución.

Keywords:

Freyina subtribe; jumping spiders; Neotropical Salticinae; taxonomy.

Palabras claves:

Subtribu Freyina; arañas saltarinas; Salticinae del Neotrópico; taxonomía.

Publicación registrada en Zoobank/ZooBank article registered

LSIDurn: Isid:zoobank.org:pub:FB86F304-53A6-44B3-9949-31A277659BD7

Acto nomenclatural/nomenclatural act:

Kalcerrytus mapinguari Portuguez, 2021

LSIDurn: Isid:zoobank.org:act:8099ABB5-70CB-4DBE-B4D4-AABEFDB465AC

Kalcerrytus yacuruna Portuguez, 2021

LSIDurn: Isid:zoobank.org:act:56EE648D-8A4E-4479-A689-7D9086F7E7CD 


\section{Introduction}

The family Salticidae is by far the richest group among spiders with 6352 species grouped in 658 genera (WSC 2021). Based on morphological and molecular data, Maddison (2015) proposed a new classification for Salticidae where he include the Freyinae Edwards (2015) as a subtribe, Freyina, within the Salticoida, in the subfamily Salticinae; those results were later corroborated by additional molecular analysis (Maddison et al. 2017). According to Galiano (2000), Kalcerrytus is close to Freya Koch 1850 , position that was later supported by phylogenetic evidence (Maddison \& Hedin 2003, Bodner \& Maddison 2008, Maddison \& Bodner 2012, Maddison et al. 2014, Maddison 2015, Maddison et al. 2017) and morphological data (Edwards 2015). Freyine spiders are a highly diversified group of neotropical salticids, Edwards (2015) proposes the presence of subdistal and subproximal prolateral tibial macrosetae in both sexes and a thick dorsoventrally tegular basal division as possible synapomorphies.

Males of Kalcerrytus differ from other freyine spiders by having robust and heavily sclerotized palps with prominent sculptured embolus base (more heavily sclerotized than Tullgrenella). They also have a long, wide, ensiform embolus, with lightly sclerotized middle area giving false appearance of terminal apophysis and turned retrolaterally; large RTA with dorsal prong elongate, sometimes slightly bifid, with or without a short ventral prong (Galiano 2000, Edwards 2015). Galiano (2000) also noted the presence of an orifice in the terminal part of the embolus, surrounded by one or more spicules. Females have a broad epigyne with an accessory pocket placed anteriorly and large copulatory openings mostly obliquely directed (Galiano 2000, Edwards 2015, Ruiz \& Brescovit 2003, Bustamante \& Ruiz 2016).

At present, the genus is composed of 18 species found in the tropical forests of Brazil, French Guiana, Bolivia, and Ecuador. Only half of the currently described species are represented for both sexes, the remaining eight are known only from males and another one is based on a single female specimen (WSC 2021). All Kalcerrytus species exhibit a similar coloration pattern that makes them difficult to differentiate; a great majority are from Brazil, among them K. amplexus Bustamante \& Ruiz, 2016, K. rosamariae Ruiz \& Brescovit, 2003, K. falcatus Ruiz \& Brescovit, 2003, K. odontophorus Ruiz \& Brescovit 2003, K. amapari Galiano, 2000, K. merreti Galiano, 2000, K. filipi Bustamante \& Ruiz, 2016, K. edwarsi Ruiz \& Brescovit, 2003, K. excultus Simon, 1902, K. leonardi Bustamante \& Ruiz, 2016, and K. leucodon Taczanowski, 1878, the latter from Ecuador, show a resemblance with some species recently discovered in Peru (Portuguez, in process), however, their genitalic characteristics allow their species recognition.

Among the salticids found during a fieldwork conducted at the Refugio Amazonas Lodge, Tambopata River, southeastern Peru, as part of the Wired Amazon initiative implemented by Rainforest Expeditions, males of two different species of Kalcerrytus were found. Examining the arachnid collection at the Museo de Historia Natural of Universidad Nacional Mayor de San Marcos (MUSM), additional males and females made possible a thorough examination of key characters at genus and species level. As part of the Wired Amazon initiative, this paper describes two new species of Kalcerrytus from Peru.

\section{Material and methods}

Type specimens are from the Tambopata River, Madre de Dios, Peru. Some of them were collected during the rainy season in March 2016, by hand and sifting leaf litter during the day. The material is deposited at the Museo de Historia Natural, Universidad Nacional Mayor de San Marcos (MUSM, D. Silva), Lima, Peru. Measurements are in millimeters and follow Galiano (1963). A protease solution was used to clear the internal female genitalia; however, a couple were cleared with $10 \% \mathrm{KOH}$ in a hot plate for 10 minutes and colored with chlorazol black (Zabra 1992). Palps were expanded alternating them between distilled water and a $\mathrm{KOH}$ oversaturated solution (Coddington 1990). The images were taken with an EOS Canon 70D digital camera attached to a Leica S APO stereomicroscope. Extended focal range images were composed with Zerene stacker 1.04 (Zerene Systems, Richland WA). The following abbreviations are used in the text and figures: ALE = anterior lateral eyes; $\mathrm{AME}=$ anterior median eyes; $\mathrm{CD}=$ copulatory duct; $\mathrm{CO}=$ copulatory opening; $\mathrm{d}=$ dorsal; $\mathrm{di}=$ distal; $\mathrm{E}=$ embolus; $\mathrm{FD}=$ fertilization duct; $\mathrm{AP}=$ accessory pocket; $\mathrm{p}=$ prolateral; $\mathrm{PLE}=$ posterior lateral eyes; $\mathrm{PME}=$ posterior median eyes; $r$ =retrolateral; RTA = retrolateral tibial apophysis; $\mathrm{S}=$ spermatheca; $\mathrm{v}=$ ventral. Localities, geographic coordinates and elevation were taken directly from labels.

\section{Taxonomy}

\section{Kalcerrytus mapinguari Portuguez, sp. nov.}

\section{Figs. 1-9}

Type material.- Male holotype (MUSM-ENT 0509667) from PERU: Madre de Dios, rio Tambopata, Refugio Amazonas Lodge, $12^{\circ} 52^{\prime} 30^{\prime \prime S} / 69^{\circ} 24^{\prime} 35^{\prime \prime W}, 231 \mathrm{~m}$, general collecting day, 7-30.iii.2016, B. Portuguez. $20 \mathrm{~Pa}-$ ratypes (10 males and 10 females): 4 males and 2 females, same data as holotype: MUSM-ENT 0512973, 0512974, 0512975 and MUSM-ENT 0512976; 6 males and 5 females from Madre de Dios, $15 \mathrm{Km}$ E Puerto Maldonado, $12^{\circ} 33^{\prime}$ S. $69^{\circ} 03^{\prime} \mathrm{W}, 200 \mathrm{~m}$, 4.iii.1990, D. Silva: MUSM-ENT 0513034, 0513036, 0513043 and MUSM-ENT 0513053; 1 male and 3 females, same data except, 26-28.vi.1989, D. Silva: MUSM-ENT 0513039 and 0513048.

Etymology:- The specific name refers to "mapinguarí" a character from Peruvian Amazon myths and represents a guardian of the forest. The name is a noun in apposition.

Diagnosis-. Males of this species resembles $K$. amplexus and $K$. rosamariae by the shape of the embolus but differs from both of them by having a bicuspid process at the base of the embolus (Figs. 3, 5). K. falcatus and $K$. odontophorus also have a process at embolus base but $K$. mapinguari sp. nov. differs from both of them by having a shorter RTA shaped as an "inverted c" letter (Fig. 4). 
(1)

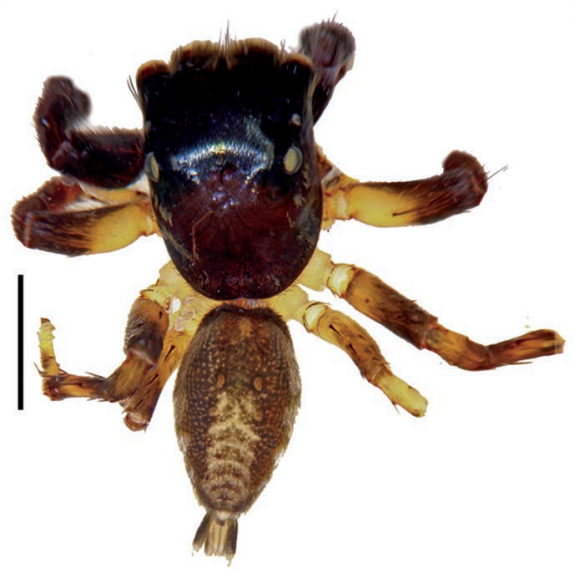

(2)

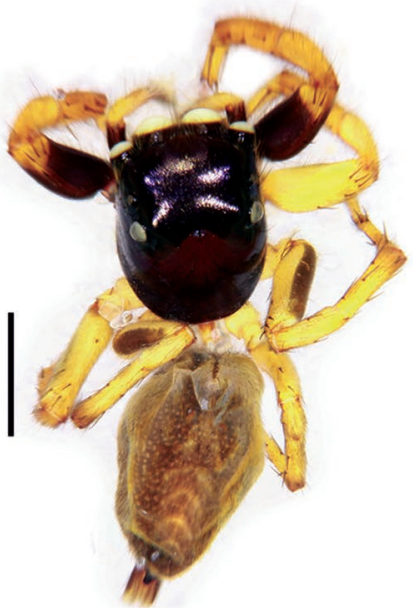

Figures 1-2. Kalcerrytus mapinguari sp. nov. 1. Male holotype MUSM-ENT 0509667, dorsal view. 2. Female paratype MUSM-ENT 0512975 dorsal view. Scale $2 \mathrm{~mm}$.

(3)

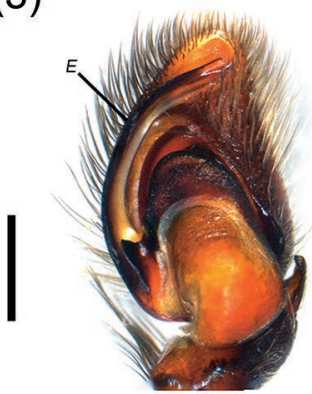

(4)

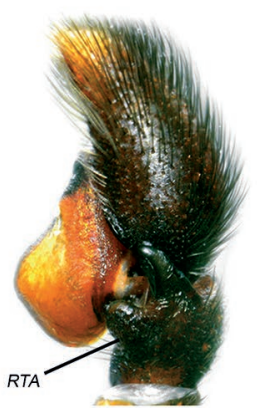

(5)

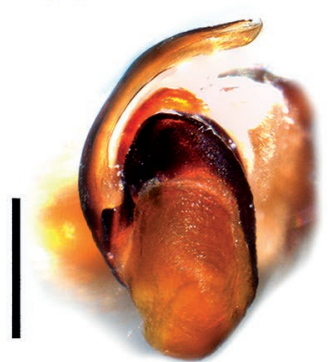

Figures 3-5. Kalcerrytus mapinguari sp. nov. Figs. 3-4, Holotype MUSM-ENT 0509667; 3. Male left palp, ventral view; 4. Male left palp, retrolateral view; Fig. 5. Paratype MUSM-ENT 0512973 5. Extended palp, ventral view. Scale: 0.4 $\mathrm{mm} . \mathrm{E}=$ embolus, $\mathrm{RTA}=$ retrolateral tibial apophysis.

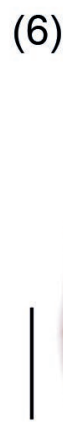

(8)
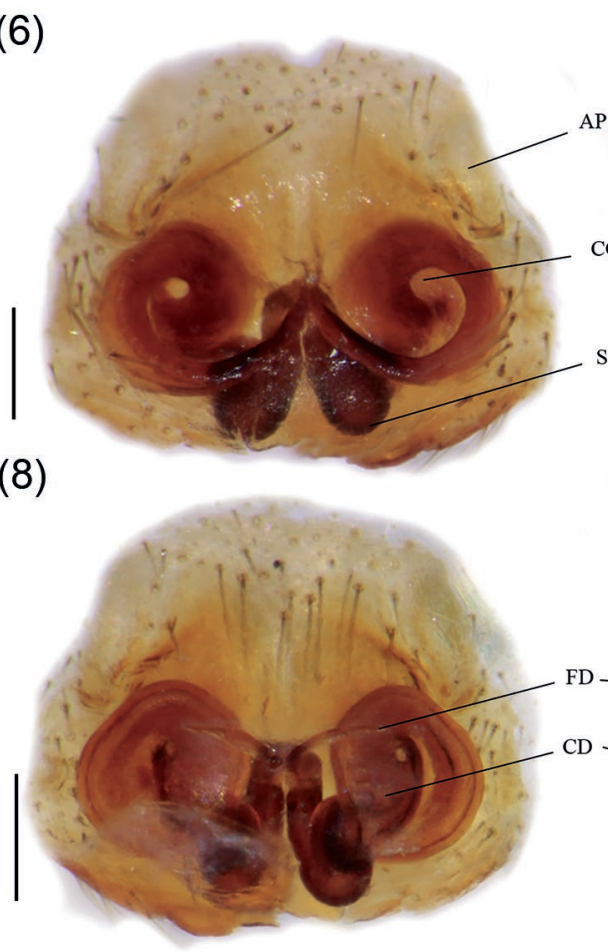

(9)

(7)
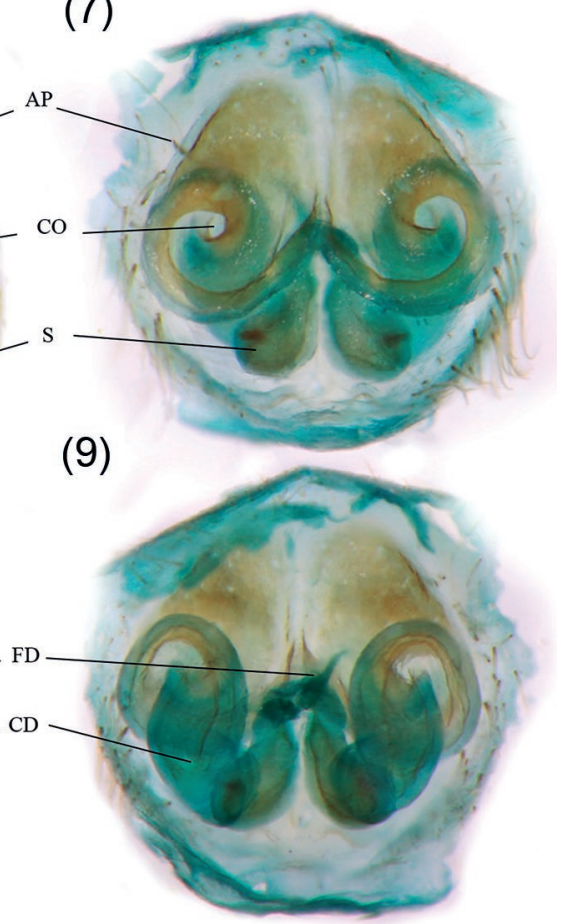

Figures 6-9. Kalcerrytus mapinguari sp. nov. Figs. 6, 8. Paratype MUSM-ENT 0512975; epigyne, cleared. Figs. 7, 9. Paratype MUSM-ENT 0512974; epigyne, cleared. 6, 7. Epigyne, ventral view; 8, 9. Epigyne, dorsal view. $A P=$ accessory pocket, $C D=$ copulatory duct, $C O=$ copulatory opening, $\mathrm{FD}=$ fertilization duct, $\mathrm{S}=$ spermatheca. Scale $0.2 \mathrm{~mm}$. 
Females are similar to K. odontophorus and $K$. leonardi for having the round copulatory openings and copulatory ducts sinuous but can be distinguished from those by the shape of the copulatory openings, comma-like (Figs. 6-7).

Description. Male (MUSM-ENT 0509667):- Total length: 6.15. Carapace 3.05 long, 2.30 wide, 1.75 high. Clypeus, 0.20 high. Ocular quadrangle 1.68 long. Anterior eye row 2.50 wide and posterior 2.28 wide. Distances ALEPME 0.70, PME-PLE 0.28. AME diameter 0.73. Chelicera with two promarginal teeth and one retromarginal tooth, as described for the tribe. Length of femur: I 2.05, II 1.95, III 2.55, IV 2.10; patella + tibia: I 2.55, II 2.20, III 2.40, IV 2.25; metatarsus + tarsus: I 1.85, II 1.75, III 2.35, IV 2.55. Leg formula: 3412. Leg spination: femur I d1-1-1, p0-0-2; II d1-1-1, p0-0-2, r0-1-2; III d1-1-1, p0-1-1, r0-1-2; IV d11-1, p0-0-2, r0-1-0; patella I-IV p1, r1; tibia I v2-2-2, p1-11; II v2-2-2 p1-1-1, r1-0-0; III v1-2, d1-0-0, p1-1-1, r1-1-1; IV v1-2, d1-0-0, p1-1-1, r1-1-1; metatarsus I-II v2-2, p00-1; III v2-2, p0-1-2, r1-1-2; IV v2-2, p1-1-2, r1-1-2. Palp (Figs. 3-4) brown, femur dorsal apical and patella dorsal and prolateral covered by white hairs, embolus thin, with a projection bicuspid on the base (Fig. 3), short RTA shaped as an "inverted c" letter as in Fig 4, femur with a round distal ventral tubercle. Color in alcohol (Fig. 1): carapace and abdomen as in the genus (Galiano 2000, Edwards 2015), with a tuft of white scales between AME and ALE, a pair of stripes of white scales extending from under PME to the posterior portion of carapace; femur, patella, tibia and tarsus I brown, metatarsus yellow; proximal femur II yellow, distal light brown, patella and tibia II light brown (median tibia lighter), metatarsus and tarsus yellow; legs III and IV yellow with brown pattern, lighter than I and II.

Female (Paratype MUSM-ENT0512975):- Total length: 7.30. Carapace 3.2 long, 2.40 wide, 1.95 high. Clypeus, 0.15 high. Ocular quadrangle 1.55 long. Anterior eye row 2.40 wide and posterior 2.15 wide. Distances ALE-PME 0.63, PME-PLE 0.28. AME diameter 0.70. Chelicera with two promarginal teeth and one retromarginal tooth, as described for the tribe. Length of femur: I 1.65, II 1.85, III 2.60, IV 2.10; patella + tibia: I 2.50, II 2.30, III 2.65, IV 2.35; metatarsus + tarsus: I 1.70, II 1.50, III 2.45, IV 2.30. Leg formula: 3412. Leg spination: femur I d1-11, p0-0-2; II d1-1-1, p0-0-2, left r0-1-1, right r0-1-0; III d1-1-1, r0-1-2, p0-0-1; IV d1-1-1, p0-0-1; patella I-II 0; III-IV p1, r1; tibia I v2-2-2, p1-0-1; II v2-2-2 p1-0-1; III v0-1-2, p1-1-1, r1-1-1; IV v0-1-2, p1-1-1, r1-1-1; metatarsus I-II v2-2; III v0-2-2, p1-1-2, r1-2; IV v0-2-2, p11-2, r1-1-2. Epygine (Figs. 6, 8): copulatory openings comma-like (Fig. 6). S-shaped copulatory ducts, sinuous and wider near the epigyne openings, oval spermatheca, fertilization ducts narrow and transversal (Fig. 8). Color in alcohol (Fig. 2): carapace and abdomen as in the genus (Galiano 2000, Edwards 2015), legs yellow, femora I dark brown and femora II, III and IV ventrally dark brown.

Variation.- 10 males: Total length 5.90-6.15; carapace long 3.15-3.28; carapace wide 2.20-2.33; carapace high 1.68-1.85; clypeus $0.13-0.18$; ocular quadrangle 1.43-1.63; anterior eyes row 2.35-2.43 wide; posterior eyes row 2.05-2.15; distance ALE-PME 0.58-0.65; dis- tance PME-PLE 0.23-0.29; AME diameter 0.70-0.73. 10 females: Total length 6.60-7.20; carapace long 3.10-3.35; carapace wide 2.38-2.55; carapace high 1.65-1.85; clypeus 0.15-0.18; ocular quadrangle 1.40-1.58; anterior eyes row 2.28-2.45 wide; posterior eyes row 2.08-2.25; distance ALE-PME 0.53-0.65; distance PME-PLE 0.250.28; AME diameter 0.70-0.75. Females may vary in retrolateral macrosetae of the left femur, $0-1-1$ or $0-1-0$.

Distribution.- Known only from Tambopata and Puerto Maldonado, in Madre de Dios, southeastern Peru.

Natural history.- They were collected among leaf litter by sifting or searching the ground.

\section{Kalcerrytus yacuruna Portuguez, sp. nov.}

\section{Figs. 10-15}

Type material.- Male holotype (MUSM-ENT 0509554) from PERU, Madre de Dios, rio Tambopata, Refugio Amazonas $12^{\circ} 52^{\prime} 30^{\prime \prime} \mathrm{S} / 69^{\circ} 24^{\prime} 35^{\prime \prime} \mathrm{W}$, general collecting, 7-30.iii.2016, B. Portuguez. Female paratype, same data as holotype, MUSM-ENT 0513028.

Etymology.- The specific name refers to "yacuruna" a mythological god that lives in the depths of the rivers and lakes of the Amazon. The name is a noun in apposition.

Diagnosis.- Males of Kalcerrytus yacuruna sp. nov. are similar to those of $K$. amapari, K. merreti, $K$. filipi and $K$. amplexus by having a short, stout RTA, but can be distinguished from $K$. amapari by the sinuous embolus with a wide base and bifurcated tip (Fig. 12). They can be distinguished from those of $K$. filipi, $K$. merreti and $K$. amplexus by having a short RTA (Fig. 13), trapezoidal in shape (RTA having a triangular in shape in $K$. filipi, quadrangular in shape in $K$. merreti with an inferior apophysis and expanded bifurcated tip in $K$. amplexus). Females are similar to those of $K$. edwarsi, K. excultus, K. leucodon by having a similar shape of copulatory ducts and spermathecae but can be distinguished from them by having an oval-shaped copulatory openings (Fig. 14).

Description. Male (Holotype MUSM-ENT 0509554).- Total length: 5.90. Carapace 2.95 long, 2.20 wide, 1.70 high. Clypeus, 0.20 high. Ocular quadrangle 1.40 long. Anterior eye row 2.20 wide and posterior 2.00 wide. Distances ALE-PME 0.55, PME-PLE 0.25. AME diameter 0.60 . Chelicera with two promarginal teeth and one retromarginal tooth, as described for the genus. Length of femur: I 1.80, II 1.75, III 2.15, IV 1.95; patella + tibia: I 2.30, II 2.00, III 2.10, IV 2.05; metatarsus + tarsus: I 1.75, II 1.65, III 2.30, IV 2.20 Leg formula: 3412. Leg spination: femur I d1-1-1, p0-0-2, r0-0-1; II d1-1-1, p0-0-2, r0-1-2; III d1-1-1, r0-1-2, p0-1-1 IV d11-1, p0-0-1, r0-1-1; patella I-IV p1, r1; tibia I v2-2-2, p1-1-1; II v2-2-2, p1-1-2, III-IV v0-1-2, d1-0-0, p1-1-2, r1-1-2; metatarsus I-II v2-2; III v2-2, p1-1-2, r-0-0-2; IV v2-2 p1-1-2, r0-1-2. Palp (Figs. 12-13): brown, femur dorsal apical and patella dorsal and prolateral covered by white hairs, embolus sinuous with a wide base (Fig. 12), RTA short, trapezoidal in shape and narrowing at 
base (Fig. 13), femur with a sub-triangular distal ventral tubercle. Color in alcohol (Fig. 10): carapace and abdomen as in the genus (Galiano 2000, Edwards 2015), with a tuft of white scales between AME and ALE, a pair of stripes of white scales extending from under PME to the posterior portion of carapace; femur, patella, tibia and tarsus I brown, metatarsus yellow; proximal femur II yellow, distal light brown, patella and tibia II light brown (median tibia lighter), metatarsus and tarsus lighter; legs III lighter than II.

\section{(10)}

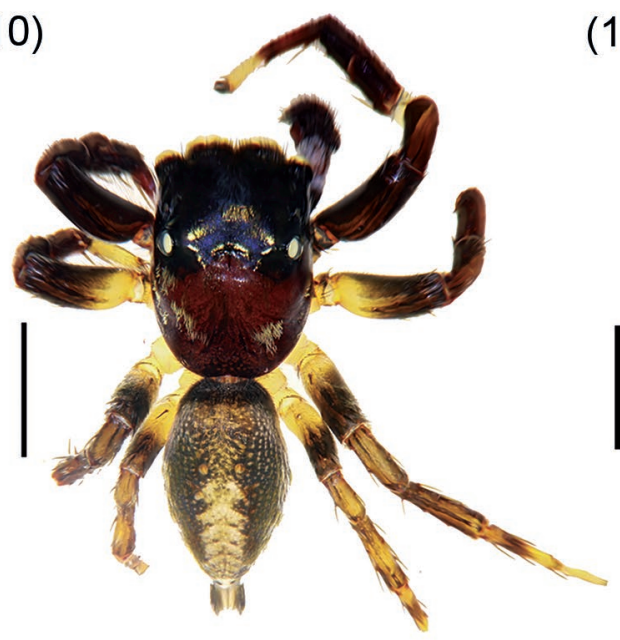

(11)

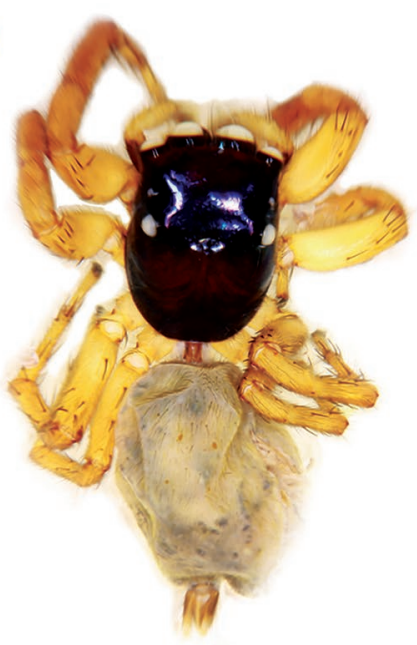

Figures 10-11. Kalcerrytus yacuruna sp. nov. 10. Male holotype MUSM-ENT 0509554, dorsal view; 11. Female paratype MUSM-ENT 0513028 dorsal view. Scale 2 mm.

(12)

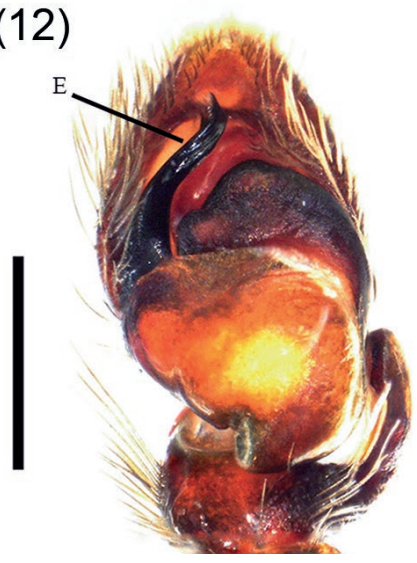

(13)

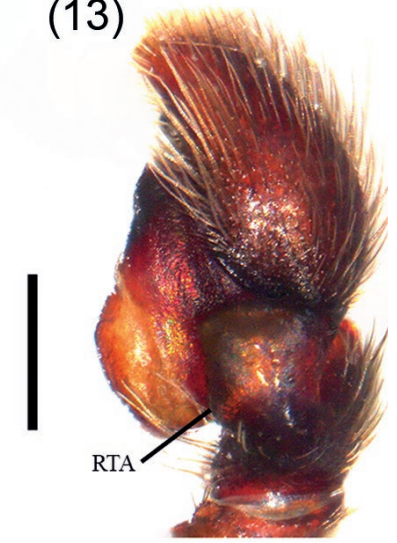

Figures 12-13. Kalcerrytus yacuruna sp. nov. Holotype MUSM-ENT 0509554; 12. Male left palp, ventral view; 13. Same, retrolateral view. Scale: $0.4 \mathrm{~mm}$. E= embolus, RTA= retrolateral tibial apophysis.

(14)

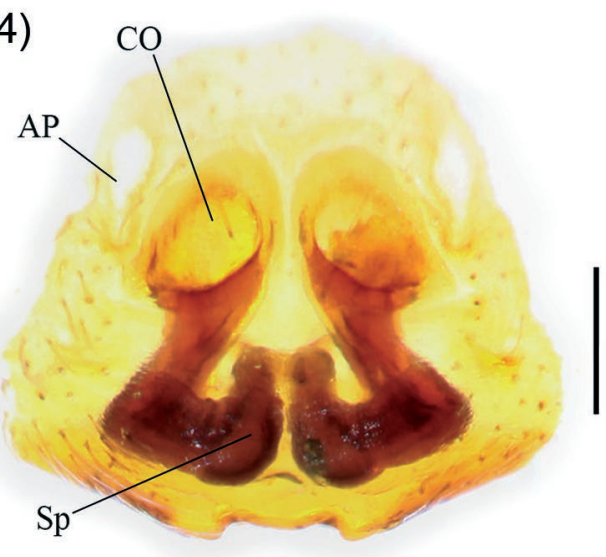

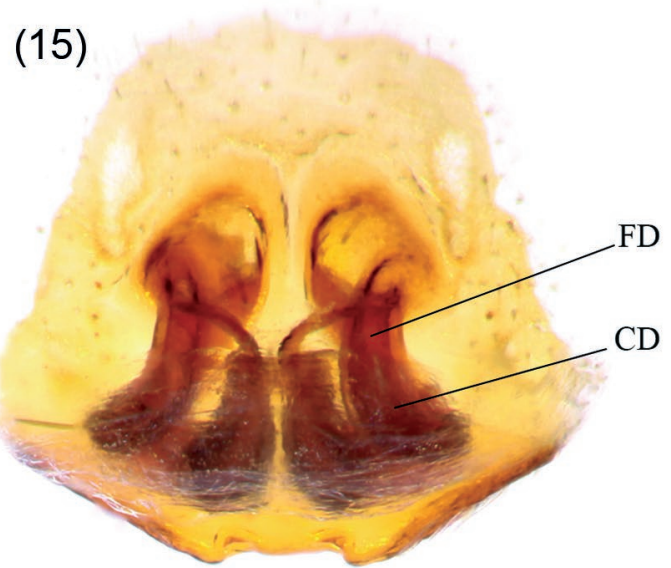

Figures 14-15. Kalcerrytus yacuruna sp. nov. Paratype MUSM-ENT 0513028; 14. Epigynum, cleared, ventral view; 15. Same, dorsal view. Scale: $0.2 \mathrm{~mm}$. $\mathrm{AP}=$ accessory pocket, $\mathrm{CO}=$ copulatory opening, $\mathrm{S}=$ spermatheca, $\mathrm{FD}=$ fertilization duct, $\mathrm{CD}=$ copulatory duct. 
Female (Paratype MUSM-ENT 0513028):- Total length: 7.40. Carapace 3.30 long, 2.40 wide, 1.90 high. Clypeus, 0.25 high. Ocular quadrangle 1.55 long. Anterior eye row 2.35 wide and posterior 2.25 wide. Distances ALE-PME 0.55, PME-PLE 0.25. AME diameter 0.70. Chelicera with two promarginal teeth and one retromarginal tooth, as described for the tribe. Length of femur: I 1.90, II 1.95 , III 2.35 , IV 1.80 patella + tibia: I 2.35, II 2.30, III 2.35, IV 2.20; metatarsus + tarsus: I 1.70, II 1.55, III 2.25, IV 2.30. Leg formula: 3412. Leg spination: femur I d1-1-1, p0-0-2; II d1-1-1, p0-0-2, r0-1-1; III d1-1-1, r0-1-2, p00-1; IV d1-1-1, p0-0-1; patella I-II 0; III-IV p1, r1; tibia
I v2-2-2, p1-0-1; II v2-2-2, p1-0-1; III v0-1-2, p1-1-1, r11-1; IV v0-1-2, p1-1-1, r1-1-1; metatarsus I-II v2-2; III v2-2, p1-1-2, r1-2; IV v2-2, p1-1-2, r1-1-2. Epygine (Figs. 14-15): sinuous copulatory ducts, wide and relatively elongated, bean-like spermathecae, fertilization ducts narrow and oblique (Fig. 15). Color in alcohol (Fig. 11): carapace and abdomen as in the genus (Galiano 2000, Edwards 2015), legs yellow.

Distribution.- Known only from the type locality.

Natural history:- They were collected among leaf litter by sifting or searching the ground.

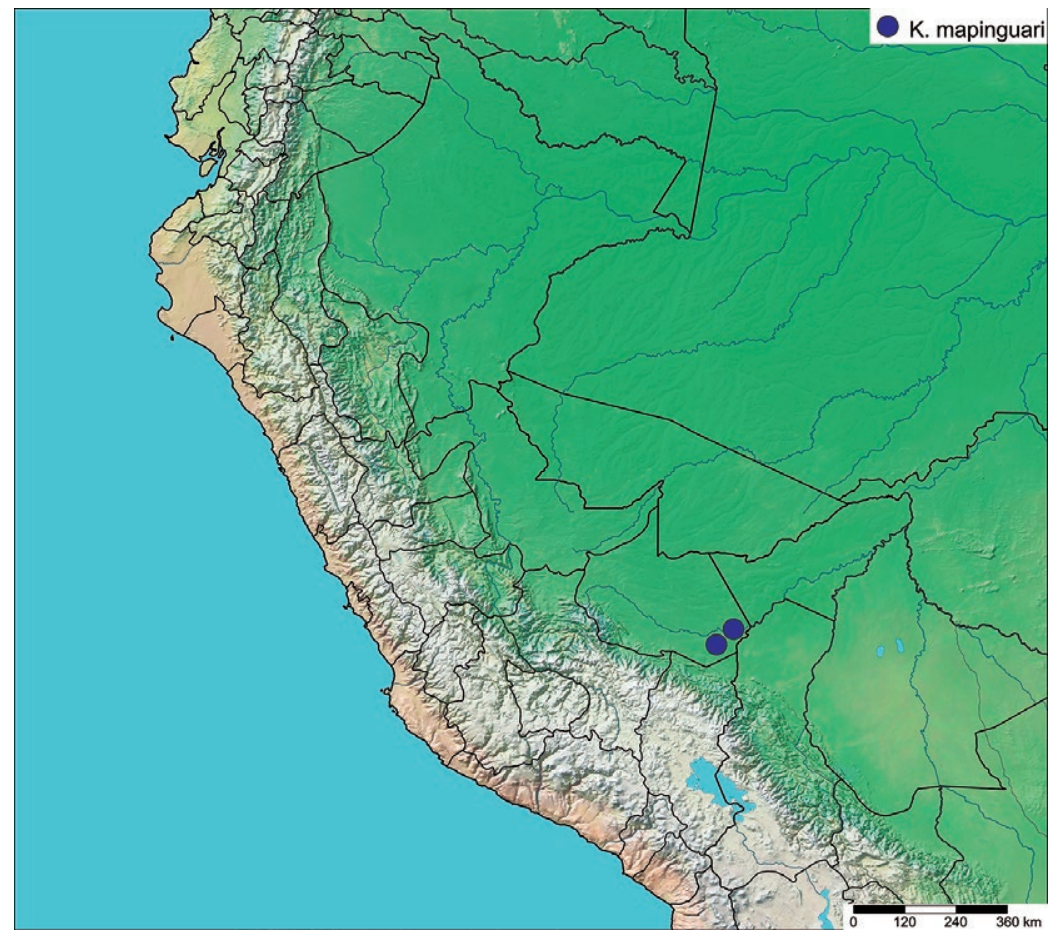

Figure 16. Locality records of Kalcerrytus mapinguari, sp. nov.

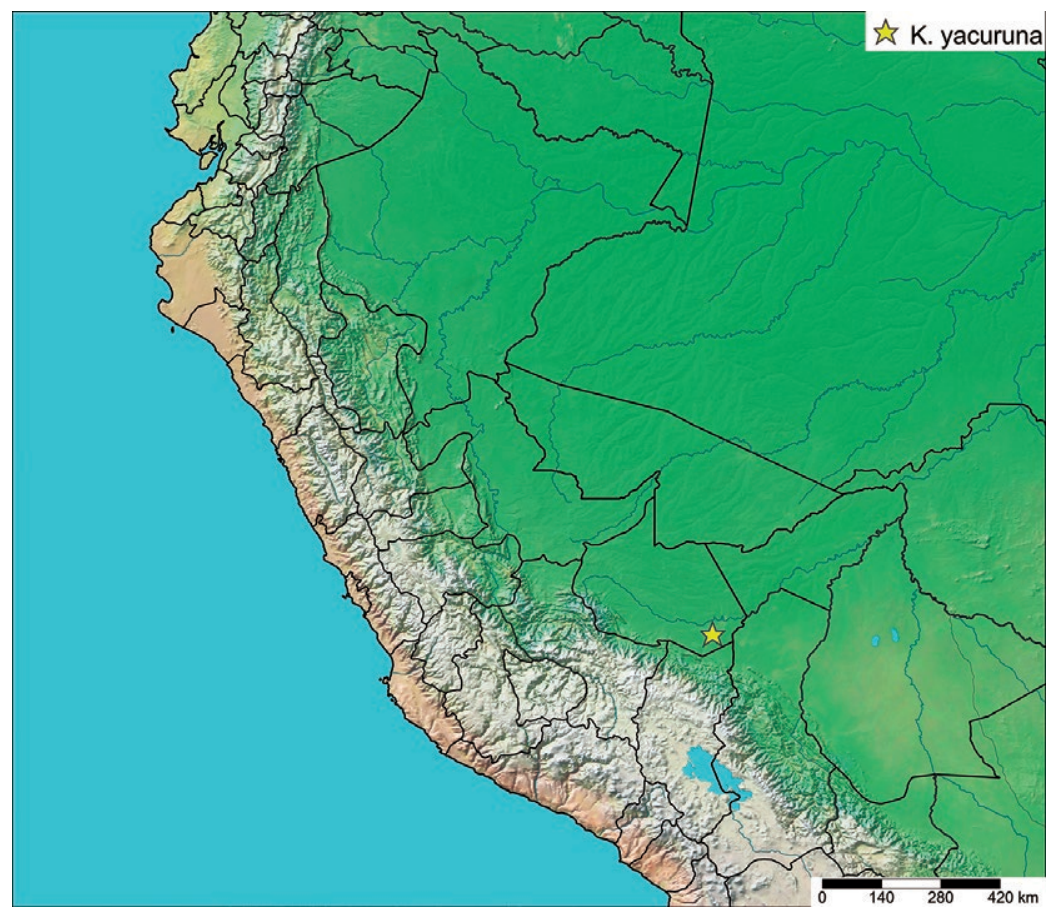

Figure 17. Locality record of Kalcerrytus yacuruna, sp. nov. 


\section{Literature cited}

Bodner M, Maddison WP. 2012. The biogeography and age of salticid spider radiations (Araneae: Salticidae). Molecular Phylogenetics and Evolution 65: 213-240. https://dx.doi.org/10.1016/j.ympev.2012.06.005

Bustamante AA, Ruiz GRS. 2016. Three new species of Kalcerrytus Galiano, 2000 from Brazil (Araneae: Salticidae). Zootaxa 4066 (1): 41-51. https://dx.doi. org/10.11646/zootaxa.4066.1.2

Coddington JA. 1990. Ontogeny and homology in the male palpus of orb weaving spiders and their relatives, with comments on phylogeny (Araneoclada: Araneoidea, Deinopoidea). Smithsonian Contributions to zoology 496: 1-52. https://doi.org/10.5479/si.00810282.496

Edwards GB. 2015. Freyinae, a major new subfamily of Neotropical jumping spiders (Araneae: Salticidae). Zootaxa 4036 (1): 1-87. http://dx.doi.org/10.11646/zootaха. 4036.1 .1

Galiano ME. 1963. Las especies americanas de arañas de la familia Salticidae descriptas por Eugène Simon: Redescripciones basadas en los ejemplares típicos. Physis 23(66): 273-470.

Galiano ME. 2000. Descripción de Kalcerrytus, nuevo género (Araneae, Salticidae). Physis C 57 (132-133): 53-71. [Buenos Aires]

Maddison WP, Hedin MC. 2003. Jumping spider phylogeny (Araneae: Salticidae). Invertebrate Systematics 17: 529-549. https://doi.org/10.1071/IS02044

Maddison WP, Bodner MR, Needham KM. 2008. Salticid spider phylogeny revisited, with the discovery of a large Australasian clade (Araneae: Salticidae). Zootaxa 1893: 49-64.

Maddison WP, Li DQ, Bodner M, Zhang JX, Xu X, Liu QQ Liu FX. 2014. The deep phylogeny of jumping spiders (Araneae, Salticidae). ZooKeys 440: 57-87. http://dx.doi. org/10.3897/zookeys.440.7891

Maddison WP. 2015. A phylogenetic classification of jumping spiders (Araneae: Salticidae). Journal of Arachnology 43: 231-292. http://dx.doi.org/10.1636/arac-43-03231-292

Maddison WP, Evans SC, Hamilton CA, Bond JE, Lemmon AR, Lemmon EM. 2017. A genome-wide phylogeny of jumping spiders (Araneae, Salticidae), using anchored hybrid enrichment. ZooKeys 695: 89-101. https://doi. org/10.3897/zookeys.695.13852

Ruiz GRS, Brescovit AD. 2003. Description of six new species of Kalcerrytus Galiano from the Brazilian Amazon (Araneae: Salticidae). Revista Ibérica de Aracnología 8: 73-79.

Shorthouse D. 2010. SimpleMappr, an online tool to produce publication-quality point maps. Online at https:// www.simplemappr.net (Accessed November 28, 2019).

World Spider Catalog. 2021. World Spider Catalog. Version 22.5. Natural History Museum Bern, online at http:// wsc.nmbe.ch (Accessed August 10, 2021). http:// dx.doi.org/10.24436/2

Żabka M. 1992. Salticidae (Arachnida: Araneae) from Oriental, Australian and Pacific regions, VII. Paraplatoides and Grayenulla-new genera from Australia and New Caledonia. Records of the Australian Museum, 44, 165183.

\section{Agradecimientos / Acknowledgments:}

The author wishes to express gratitude to Rainforest Expeditions and to the field staff of the Wired Amazon project; thanks are due to Daniel Couceiro and Juan Grados for their assistance with the logistics for the fieldwork; also, I thank Diana Silva, curator of the MUSM collection, and two anonymous reviewers for helping to improve this paper.

Conflicto de intereses / Competing interests:

The author declare no conflict of interest.

\section{Rol de los autores / Authors Roles:}

Does not apply.

\section{Fuentes de financiamiento / Funding:}

This work has been carried out under the project "Discovery new species and Amazon Cam", co-financed by the "Programa Nacional de innovación para la Competitividad y ProductividadInnóvate Perú".

Aspectos éticos / legales; Ethics / legals:

Authors declare that they did not violate or omit ethical or legal norms in this research. Permit of collect $N^{\circ} 301-2015-S E R F O R /$ DGGSPFFS, Servicio Forestal y de Fauna Silvestre-SERFOR-Perú 
Página en banco

Blank page 